\title{
Refractory chronic spontaneous urticaria after the use of alemtuzumab in multiple sclerosis
}

Hannah Hu, MBBS, MMed, Stephen Reddell, MBBS, PhD, Sean Riminton, MBChB, PhD, Charles Chan, MBBS, PhD, and Nicolás Urriola, MBBS

Neurol Neuroimmunol Neuroinflamm 2020;7:e661. doi:10.1212/NXI.0000000000000661 e661

A 40-year-old woman developed erythematous, raised and pruritic, migratory lesions on a daily basis affecting her whole body for the past 3 months; the appearance of the rash was consistent with urticaria. There was associated angioedema affecting her lips and face. Her medical history was significant for MS, diagnosed 9 years before, manifesting clinically with mobility, speech, and cognitive impairment. Initial treatment was with $\beta$-interferon and glatiramer acetate; however, disease relapse prompted switching to alemtuzumab, with 2 standard courses given 12 months apart (60 and $36 \mathrm{mg}$, respectively, the last dose given 12 months before the onset of rash), and achieved remission with a new baseline Expanded Disability Status Scale of 2.

Ancillary history includes short-lived, asymptomatic, subclinical hypothyroidism before 13 years for which she was given thyroxine during pregnancy. Months after her first dose of alemtuzumab, she developed mild symptomatic hyperthyroidism with persistent thyroglobulin antibodies. Carbimazole was given for a year but ceased after her thyroid function tests normalized. She remained persistently thyroglobulin antibody seropositive. No other subsequent secondary autoimmune diseases manifested with otherwise normal laboratory results.

At the time of development of urticaria, she was on long-term venlafaxine and dexamphetamine for a mood disorder. There was no history to suggest an allergic reaction to current medications. Differential blood count, C-reactive protein, and erythrocyte sedimentation rate did not suggest any chronic or recurrent infections triggering urticaria. Specific IgE to dust mite, grass pollen mix, and staple food was negative.

A clinical diagnosis of chronic spontaneous urticaria (CSU) was made, and she was treated with a maximal dose of histamine $(\mathrm{H} 1 / \mathrm{H} 2)$ receptor blockade (cetirizine $20 \mathrm{mg}$ bis die and ranitidine $150 \mathrm{mg}$ bis die). Despite this treatment, she continued to have breakthrough urticaria and required intermittent high dose prednisolone $(1 \mathrm{mg} / \mathrm{kg} / \mathrm{d})$ while still scoring 42 on the Urticaria Activity Score over 7 Days scale. Therapy was intensified with omalizumab (300 mg monthly), because of its demonstrated efficacy in $\mathrm{CSU}^{1}$ and low side-effect profile as compared to other agents used in treatment of alemtuzumab-related secondary autoimmunity. This resulted in a dramatic (but incomplete) reduction in urticaria, with burdensome breakthrough lesions typically in the week before her next omalizumab dose.

No clinical relapses or new signs of radiologic MS activity occurred over this period; her MS continued to improve throughout omalizumab therapy with the Expanded Disability Status Scale score improving from 2 to 0 , over 18 months of monitoring.

A skin biopsy was performed that excluded other causes of immune-mediated urticaria, securing the diagnosis of $\mathrm{CSU}^{2}$ (see figure 1 and figure e-1, links.lww.com/NXI/A186). Montelukast was initiated at $10 \mathrm{mg} / \mathrm{d}$ and advised to adhere to a strict 28-day dosing of omalizumab to minimize the breakthrough period.

\author{
Correspondence \\ Dr. $\mathrm{Hu}$ \\ hannah.hu@health.nsw.gov.au
}


Figure A perilesional skin biopsy showed mild, superficial, dermal perivascular lymphocytic infiltrate and mild dermal oedema with dilated lymphatics

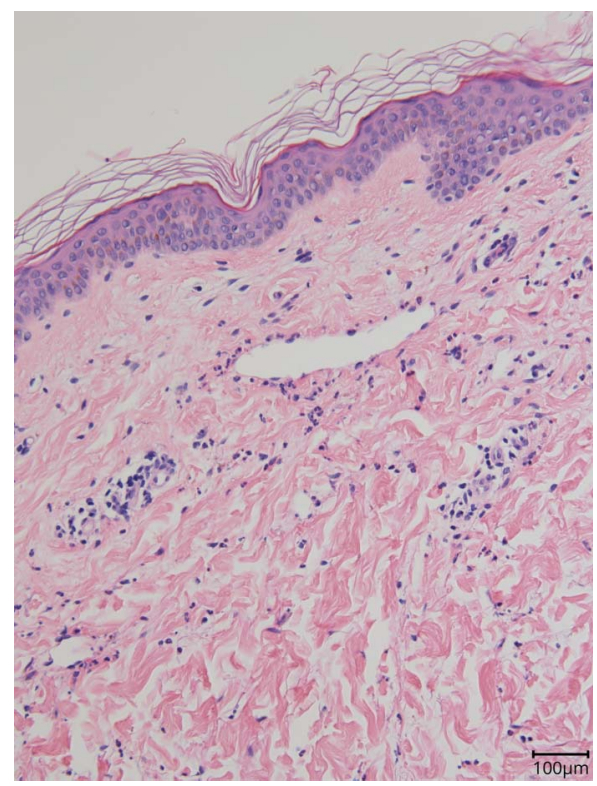

Neutrophils were seen within the lumen of the vessels and scattered in small numbers through interstitium together with occasional mast cells. The findings were consistent with chronic urticaria. No evidence of vasculitis was seen.

\section{Discussion}

Alemtuzumab is a monoclonal antibody directed against the CD52 antigen. It is used therapeutically in chronic lymphocytic leukemia and increasingly in MS. The CD52 antigen is expressed on $>95 \%$ of peripheral $\mathrm{B}$ and $\mathrm{T}$ lymphocytes, monocytes, macrophages, and thymocytes. Binding of alemtuzumab to the CD52 antigen causes lysis of the target cell, and its clinical efficacy is because of $\mathrm{B}$ and $\mathrm{T}$ lymphocyte, monocyte, and natural killer cell depletion. ${ }^{3}$

Immune dysregulation after alemtuzumab has been reported at rates up to $30 \%$, with common manifestations being thyroid diseases and autoimmune hematologic conditions. ${ }^{3}$ Autoimmune side effects manifested at 6 months with a peak incidence in year 3 after the first course. ${ }^{4}$ It is postulated the autoimmune sequelae arise from reconstitution of cells after T-cell lymphopenia along with additional insults including the depletion of Tregs and overproduction of interleukin-21. ${ }^{5} \mathrm{~T}$ cells undergo homeostatic proliferation to reconstitute the immune system relying on stimulation through the T-cell receptor-self peptide-major histocompatibility complex and leads to generation of self-reactive $\mathrm{T}$ cells. ${ }^{5}$

CSU is the appearance of wheals and/or angioedema for longer than 6 weeks. ${ }^{1}$ It can be because of autoantibodies or idiopathy. ${ }^{2}$ The treatment paradigm is high-dose H1-antagonists (up to 4 times the usual recommended dose), $\mathrm{H}-2$ antagonists, and adjuvants such as leukotriene antagonists. If symptoms remain refractory, the most effective next-line agent is omalizumab.
Omalizumab is a humanized immunoglobulin $\mathrm{G}$ directed against immunoglobulin $\mathrm{E}$ and is thought to not only bind serum $\operatorname{IgE}$ but also downregulate its cognate receptor $\left(\mathrm{Fc}_{\mathrm{c}} \mathcal{E R}-1\right)$ on mast cells; it has demonstrated efficacy in severe, autoimmune CSU. ${ }^{6}$

We believe that this is the first reported case of CSU in the context of immune dysregulation within the typical time period after alemtuzumab and thus adds to the expanding repertoire of alemtuzumab-related immune-mediated side effects. Previous reports of urticaria were solely acute infusionrelated side effects. ${ }^{7}$ It is important to consider CSU as a cause of recurrent rashes and angioedema after alemtuzumab because disease specific therapy is effective and available.

\section{Study funding}

No targeted funding reported.

\section{Disclosure}

Disclosures available: Neurology.org/NN.

\section{Publication history}

Received by Neurology: Neuroimmunology \& Neuroinflammation May 24, 2019. Accepted in final form December 11, 2019.

\section{Appendix Authors}

\begin{tabular}{|c|c|c|c|}
\hline Name & Location & Role & Contribution \\
\hline $\begin{array}{l}\text { Hannah } \\
\text { Hu, MBBS, } \\
\text { MMed }\end{array}$ & $\begin{array}{l}\text { Concord Repatriation } \\
\text { General Hospital, } \\
\text { Australia }\end{array}$ & Author & $\begin{array}{l}\text { Compilation of patient } \\
\text { history; drafted the } \\
\text { manuscript for } \\
\text { intellectual content }\end{array}$ \\
\hline $\begin{array}{l}\text { Stephen } \\
\text { Reddell, } \\
\text { MBBS, } \\
\text { PhD }\end{array}$ & $\begin{array}{l}\text { Concord Repatriation } \\
\text { General Hospital, } \\
\text { University of Sydney, } \\
\text { Australia }\end{array}$ & Author & $\begin{array}{l}\text { Compilation of patient } \\
\text { history; revised the } \\
\text { manuscript for } \\
\text { intellectual content }\end{array}$ \\
\hline $\begin{array}{l}\text { Sean } \\
\text { Riminton, } \\
\text { MBChB, } \\
\text { PhD }\end{array}$ & $\begin{array}{l}\text { Concord Repatriation } \\
\text { General Hospital, } \\
\text { University of Sydney, } \\
\text { Australia }\end{array}$ & Author & $\begin{array}{l}\text { Compilation of patient } \\
\text { history; revised the } \\
\text { manuscript for } \\
\text { intellectual content }\end{array}$ \\
\hline $\begin{array}{l}\text { Charles } \\
\text { Chan, } \\
\text { MBBS, } \\
\text { PhD }\end{array}$ & $\begin{array}{l}\text { Concord Repatriation } \\
\text { General Hospital, } \\
\text { University of Sydney, } \\
\text { Australia }\end{array}$ & Author & $\begin{array}{l}\text { Compilation of patient } \\
\text { history; interpreted } \\
\text { the data }\end{array}$ \\
\hline $\begin{array}{l}\text { Nicolás } \\
\text { Urriola, } \\
\text { MBBS }\end{array}$ & $\begin{array}{l}\text { Concord Repatriation } \\
\text { General Hospital, } \\
\text { University of Sydney, } \\
\text { Australia }\end{array}$ & Author & $\begin{array}{l}\text { Compilation of patient } \\
\text { history; revised the } \\
\text { manuscript for } \\
\text { intellectual content }\end{array}$ \\
\hline
\end{tabular}

\section{References}

1. Maurer M, Rosen $\mathrm{K}$, Hsieh HJ, et al. Omalizumab for the treatment of chronic idiopathic or spontaneous urticaria. N Engl J Med 2013;368:924-935.

2. Saini SS. Chronic spontaneous urticaria. Immunol Allergy Clin North Am 2014;34:33-52

3. Guarnera C, Bramanti P, Mazzon E. Alemtuzumab: a review of efficacy and risks in the treatment of relapsing remitting multiple sclerosis. Ther Clin Risk Manag 2017;13:871-879.

4. Decallonne B, Bartholomé E, Delvaux V, et al. Thyroid disorders in alemtuzumabtreated multiple sclerosis patients: a Belgian consensus on diagnosis and management. Acta Neurol Belg 2018;118:153-159.

5. Jones JL, Phuah CL, Cox AL, et al. IL-21 drives secondary autoimmunity in patients with multiple sclerosis, following therapeutic lymphocyte depletion with alemtuzumab (Campath-1H). J Clin Invest 2009;119:2052-2061.

6. Kaplan AP. Chronic spontaneous urticaria: pathogenesis and treatment considerations. Allergy Asthma Immunol Res 2017;9:477-482.

7. Uppenkamp M, Engert A, Diehl V, Bunjes D, Huhn D, Brittinger G. Monoclonal antibody therapy with CAMPATH-1H in patients with relapsed high- and low-grade non-Hodgkin's lymphomas: a multicenter phase I/II study. Ann Hematol 2002;81:26-32. 


\title{
Neurology \\ Neuroimmunology \& Neuroinflammation
}

\author{
Refractory chronic spontaneous urticaria after the use of alemtuzumab in multiple \\ sclerosis \\ Hannah Hu, Stephen Reddell, Sean Riminton, et al. \\ Neurol Neuroimmunol Neuroinflamm 2020;7; \\ DOI 10.1212/NXI.0000000000000661
}

This information is current as of January 8, 2020

Neurol Neuroimmunol Neuroinflamm is an official journal of the American Academy of Neurology.

Published since April 2014, it is an open-access, online-only, continuous publication journal. Copyright

Copyright $\odot 2020$ The Author(s). Published by Wolters Kluwer Health, Inc. on behalf of the American

Academy of Neurology.. All rights reserved. Online ISSN: 2332-7812.

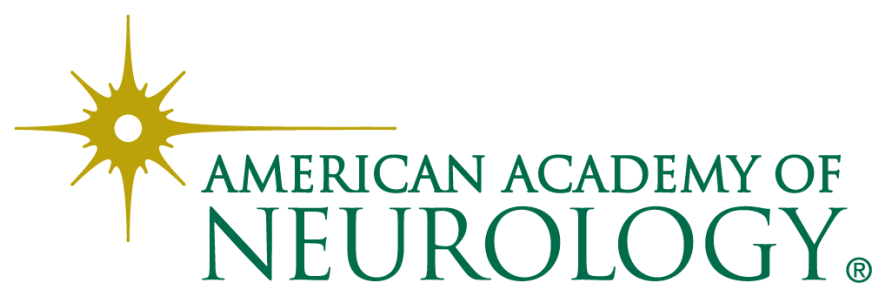




\section{Updated Information \& Services}

References

Citations

Subspecialty Collections

Permissions \& Licensing

Reprints including high resolution figures, can be found at:

http://nn.neurology.org/content/7/2/e661.full.html

This article cites 7 articles, 0 of which you can access for free at: http://nn.neurology.org/content/7/2/e661.full.html\#\#ref-list-1

This article has been cited by 1 HighWire-hosted articles: http://nn.neurology.org/content/7/2/e661.full.html\#\#otherarticles

This article, along with others on similar topics, appears in the following collection(s):

All Clinical Neurology

http://nn.neurology.org//cgi/collection/all_clinical_neurology All Immunology

http://nn.neurology.org//cgi/collection/all_immunology

Autoimmune diseases

http://nn.neurology.org//cgi/collection/autoimmune_diseases

Multiple sclerosis

http://nn.neurology.org//cgi/collection/multiple_sclerosis

Information about reproducing this article in parts (figures,tables) or in its entirety can be found online at:

http://nn.neurology.org/misc/about.xhtml\#permissions

Information about ordering reprints can be found online:

http://nn.neurology.org/misc/addir.xhtml\#reprintsus

Neurol Neuroimmunol Neuroinflamm is an official journal of the American Academy of Neurology.

Published since April 2014, it is an open-access, online-only, continuous publication journal. Copyright

Copyright $\odot 2020$ The Author(s). Published by Wolters Kluwer Health, Inc. on behalf of the American

Academy of Neurology.. All rights reserved. Online ISSN: 2332-7812.

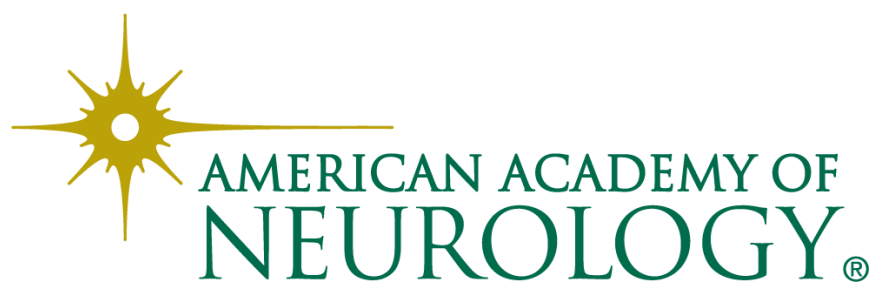

